\title{
QUANTITATIVE VS. CONVENTIONAL PCR FOR DETECTION OF HUMAN ADENOVIRUSES IN WATER AND SEDIMENT SAMPLES
}

Rodrigo STAGgEMEIER(1), Marina BORTOLUZZI(1), Tatiana Moraes da Silva HECK(1), Fernando Rosado SPILKI(1) \& Sabrina Esteves de Matos ALMEIDA(1)

\begin{abstract}
SUMMARY
Human Adenoviruses (HAdV) are notably resistant in the environment. These agents may serve as effective indicators of fecal contamination, and may act as causative agents of a number of different diseases in human beings. Conventional polymerase chain reaction (PCR) and, more recently, quantitative PCR (qPCR) are widely used for detection of viral agents in environmental matrices. In the present study PCR and SYBR $®$ Green qPCR assays were compared for detection of HAdV in water (55) and sediments (20) samples of spring and artesian wells, ponds and streams, collected from dairy farms. By the quantitative methodology HAdV were detected in $87.3 \%$ of the water samples and $80 \%$ of the sediments, while by the conventional PCR $47.3 \%$ and $35 \%$ were detected in water samples and sediments, respectively.
\end{abstract}

KEYWORDS: Adenovirus; Quantitative PCR; Conventional PCR; Water; Sediment.

\section{INTRODUCTION}

Human adenoviruses (HAdV), belong to the family Adenoviridae, gender Mastadenovirus, and are classified into seven species, A to G, now comprising more than 60 types $^{17}$. The type $\mathrm{F}$ is formed by HAdV enteric serotypes that grow in cell cultures; $\mathrm{AdV}-40$ and $\mathrm{AdV}-41^{34}$; respiratory types -2 and -5 are often reported as water contaminants ${ }^{13}$. The HAdV virion particle consists of an icosahedral, non-enveloped capsid with a diameter ranging between 70 to $100 \mathrm{~nm}$. The viral genome is composed of double-stranded linear $\mathrm{DNA}^{34}$.

HAdV are distributed worldwide and are responsible for causing, among other diseases, diarrhea and conjunctivitis related to consumption or contact with contaminated water ${ }^{19}$. Gastroenteritis associated with HAdV occurs in children and adults, the HAdV-40 and -41 being important etiological agents ${ }^{30}$. In industrialized countries, the incidence varies from one to $8 \%$ while in developing countries between two and $31 \%{ }^{24}$. The HAdV has often been identified in various environmental samples such as wastewater ${ }^{16}$, drinking water ${ }^{21}$, groundwater ${ }^{27}$, surface water ${ }^{29}$ and recreational waters ${ }^{43}$. HAdV are excreted at high densities in human feces ${ }^{39}$, and occur in sewage, raw water, and treated water and have also been detected in shellfish ${ }^{5}$. In 2005, they were included in the "Contaminant Candidate List 2" from the U.S. Environmental Protection Agency ${ }^{37}$, due their sanitary importance, fecal-oral route of infection, and frequent occurrence in many aquatic environments.

Molecular techniques are generally based on detection of highly conserved portions of the viral genome ${ }^{1}$. The most commonly used method, considered the gold standard in several areas including virology $y^{22,40}$, is the Polymerase Chain Reaction (PCR), which offers advantages over cell culture methods in the detection of viruses in environmental samples. PCR is faster, has high sensitivity and specificity ${ }^{15,28}$ since properly developed and standardized, however, this methodology has limitations, such as the use of gel electrophoresis with dyes that can be harmful to human health and the inability to quantify the results ${ }^{26,40}$.

In clinical research, there are already some comparisons between PCR and quantitative PCR PC, $^{2,6,11,25,36}$ (qPCR); these studies indicated a higher sensitivity of qPCR compared to $\mathrm{PCR}^{3}$. The mechanisms by which the qPCR can be more sensitive than PCR have been described ${ }^{14,35}$, among them, qPCR perform the quantitation of the target gene during exponential amplification avoiding problems that are associated with the so-called 'end-point' of PCR in which amplicons are only analyzed after completion of the final PCR cycle ${ }^{35}$; it is only during this exponential phase of the PCR that it will be possible to determine the starting amount of template ${ }^{14}$. Moreover, qPCR usually requires lower concentrations of target genomic DNA $(<1000 \mathrm{X})^{14,35}$. In addition, environmental samples may harbor several kinds of substances that partially inhibit the amplification; the use of qPCR may result in a lower incidence of false negatives and a higher reliability of results ${ }^{31}$. Regarding costs, when reagents and kits are considered, some studies show that there is an equivalence in costs between conventional PCR and qPCR (using SYBR $^{\circledR}$ Green $)^{26,36}$. 


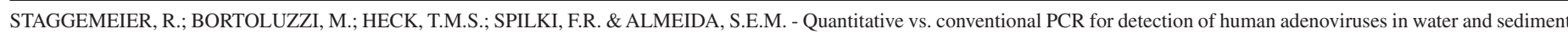
samples. Rev. Inst. Med. Trop. Sao Paulo, 57(4): 299-303, 2015.

The aim of this study was to compare these two molecular methods, conventional PCR and qPCR for the detection of HAdV in water and sediment samples.

\section{METHODS}

Sample collection: The municipalities of Rolante and Riozinho, located in Vale do Paranhana, Rio Grande do Sul, Brazil, have most of its population living in small farms, and their economy is based on dairy production. In addition, some of the properties also have cattle, poultry, swine and fish. The three main rivers in the region are Rolante, Areia and Riozinho. In the summer of March 2011, 55 water samples and 20 sediment samples were obtained from springs (including tap water), artesian wells, ponds and streams located at the municipalities of Riozinho and Rolante, Rio Grande do Sul, Brazil. Water samples (26 springs, 11 artesian wells, eight ponds, 10 streams) were collected aseptically in sterile glass vials $(0.5 \mathrm{~L})$. From the sediment samples (seven springs, five ponds, eight streams), $100 \mathrm{~g}$ were collected aseptically in sterile glass bottles, 20 collection points of the sediments were the same points of collection of water samples. After collection, the samples were stored for 48 hours at $4{ }^{\circ} \mathrm{C}$ until further processing.

Viral concentration in water samples: the waters were concentrated using an adsorption-elution method with negatively charged membranes (HA, Millipore, USA), based on the method proposed by KATAYAMA et al. $(2002)^{20}$ with few modifications ${ }^{7,38}$. Briefly, $0.6 \mathrm{~g}$ of $\mathrm{MgCl}_{2} \cdot 6 \mathrm{H}_{2} \mathrm{O}$ was mixed with $500 \mathrm{~mL}$ of each water sample and $\mathrm{pH}$ was adjusted to 5.0 using a solution of $10 \% \mathrm{HCl}$. Subsequently, the resulting mixture was vacuum filtered through a negatively sterile membrane (type HA, 0.45 $\mathrm{mm}$ pore size; $47 \mathrm{~mm}$ diameter). The membrane was rinsed with 87.5 $\mathrm{mL}$ of a $0.5 \mathrm{mM} \mathrm{H}_{2} \mathrm{SO}_{4}(\mathrm{pH} 3.0)$ followed by elution of viral particles adsorbed to the membrane with $2.5 \mathrm{~mL}$ of $1 \mathrm{mM} \mathrm{NaOH}(\mathrm{pH} 10.5)$. The filtrate was then neutralized with $12.5 \mu \mathrm{L}$ of $50 \mathrm{mM} \mathrm{H}_{2} \mathrm{SO}_{4}$ and $12.5 \mu \mathrm{L}$ in 100xTris-EDTA (TE) buffer. The resulting mixture was aliquoted and stored at $-80{ }^{\circ} \mathrm{C}$ until further processing. This procedure has an average concentration efficacy of $50 \%$.

Viral recovery in sediments: for each sediment sample, $1 \mathrm{~g}$ of the solid fraction was diluted in $1 \mathrm{~mL}$ of Eagle's Minimal Essential Medium (E-MEM, pH 10.5, Nutricell, Campinas, Brazil) to allow the extraction of nucleic acids for molecular tests and subsequent viral isolation in cell culture. The solution was homogenized by vortexing for one minute and then centrifuged at 14,000 rpm for 10 minutes. The supernatant was used for the extraction of viral DNA.

Extraction of viral DNA/ PCR/ qPCR: The viral genomes present in the samples were extracted by the extraction kit RTP ${ }^{\circledR}$ DNA/RNA Virus Mini Kit (Stratec ${ }^{\mathrm{TM}}$, Birkenfeld, Germany). For molecular detection of HAdV conventional PCR and qPCR were performed with the same set of primers VTB2 HAdvC, according to WOLF et al. (2010) ${ }^{42}$ ([hexon gene, positions 106-126] 5 '-GAGACGTACTTCAGCCTGAAT-3'; [190207] 5'-GATGAACCGCAGCGTCAA-3'), with annealing temperature at $55^{\circ} \mathrm{C}$. For all reactions positive and negative controls were added, and the GoTaq ${ }^{\circledR}$ Green Master Mix $2 X$ (Promega, Madison, USA), was used following the manufacturer's instructions; in $50 \mu \mathrm{L}$ of total volume, reaction mixtures consisted of $25 \mu \mathrm{L}$ of GoTaq ${ }^{\circledR}$ Green Master Mix, $18 \mu \mathrm{L}$ of nuclease-free water, $1 \mu \mathrm{L}$ of each primer $(20 \mathrm{pM})$, and $5 \mu \mathrm{L}$ of DNA. Amplification of the target genomic fragments was performed using a thermal cycler (MultiGene ${ }^{\circledR}$, Labnet International, Edison, USA). After the reaction, amplification products were analyzed by electrophoresis in $2 \%$ agarose gel stained with ethidium bromide and subsequently visualized under UV light. The qPCR was performed with a commercial kit Platinum ${ }^{\circledR}$ SYBR $^{\circledR}$ Green qPCR SuperMix-UDG (Invitrogen ${ }^{\mathrm{TM}}$, Carlsbad, USA), following the manufacturer's instructions. In a total of $25 \mu \mathrm{L}, 5 \mu \mathrm{L}$ of DNA, $1 \mu \mathrm{L}$ of each primer (20 pM) (VTB2-R; VTB2-F), $12.5 \mu \mathrm{L}$ of supermix SYBR ${ }^{\circledR}$ Green qPCR [Platinum ${ }^{\circledR}$ Taq DNA polymerase, $\mathrm{SYBR}^{\circledR}$ Green I Dye, Tris-HCl, $\mathrm{KCl}, 6 \mathrm{mM} \mathrm{MgCl}$, $400 \mu \mathrm{M}$ of dGTP, $400 \mu \mathrm{M}$ dATP, $400 \mu \mathrm{M}$ dCTP, $800 \mu \mathrm{M}$ dUTP, uracil DNA glycosilase (UDG)], and $5.5 \mu \mathrm{L}$ of distilled water free from RNAses (RNAse/DNAse free water system, Merck-Millipore, Darmstadt, Germany) were used. The qPCR reactions were conducted in a thermal cycler iQ5 $^{\mathrm{TM}}$ Bio-Rad (Biorad ${ }^{\mathrm{TM}}$, Hercules, USA). Each reaction was composed of a denaturation cycle of $95{ }^{\circ} \mathrm{C}$ by $10 \mathrm{~min}$. followed by 40 cycles composed of one step of $95^{\circ} \mathrm{C}$ for $20 \mathrm{~s}$, and combined annealing/ extension steps at $55^{\circ} \mathrm{C}$ for one minute. After, a melting curve was built to check the specificity of amplification products. For generating standard curves, 10-fold serial dilutions of standard controls from $10^{-1}$ to $10^{-5}$ were prepared, starting at $6.01 \times 10^{7}$ genome copies equivalents per reaction (HAdV-5). Positive controls were AdV type 5 (Ad5 prototype strain) cultivated in A549 in our facilities. The same AdV type 5 virus was used to build the standard control curve throughout the study. All standard controls and samples were run in duplicates; the limit of detection was found to be 40 to 60 genome copies per reaction, the efficiency was $96.5 \%(\mathrm{R} 2=0.99$, slope $=-3.41)$. No template control $(\mathrm{NTC})$, and $\mathrm{AdV}$ negative samples were used in each run to ensure the absence of contamination in the assay. Melting curve analysis was performed using High Resolution Melting electrophoresis (HRM) to verify PCR product specificity; $\mathrm{HAdV}$ melting temperature was $86.5^{\circ} \mathrm{C} \pm 0.5$.

\section{RESULTS}

Quantitative PCR results were expressed as genome copies/L in water samples and as genome copies/g in sediment samples. The results obtained using the conventional PCR for water and sediment were $47.3 \%$ $(26 / 55)$ and $35 \%(7 / 20)$, respectively while the results in the qPCR detection were $87.3 \%$ (48/55) for water and $80 \%$ (16/20) for sediment (Table 1). All positive samples by PCR were also positive by qPCR. The results were previously compared to those obtained in assays using 1:10 dilutions of the extracted DNA, but no differences were observed (data not shown).

\section{DISCUSSION}

The primers used for HAdV in both methods were the same, therefore allowing a correct comparison. This same pair of primers was used several times in conventional PCR with satisfactory results ${ }^{7,38}$. A highly sensitive technique for viral detection is needed in order to ascertain the presence of the virus in environmental samples ${ }^{41}$.

The qPCR of this study showed a higher detection rate when compared to conventional PCR. In addition ${ }^{10,16,32}$, due to $\mathrm{qPCR}$ characteristics, this methodology allows the elimination of the post-amplification laborious work (use of gel electrophoresis and ethidium-bromide staining) that is required for the observation of amplified products. Furthermore, the entire analysis can be accomplished in a closed system which reduces the potential for carry-over ${ }^{26}$. Another advantage is the ability to closely 


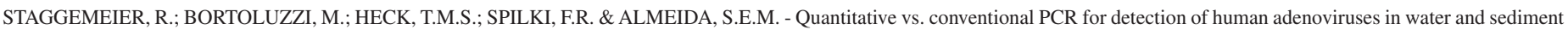
samples. Rev. Inst. Med. Trop. Sao Paulo, 57(4): 299-303, 2015.

Table 1

Results of PCR and qPCR Adenovirus analysis in water (qPCR; genome copies/L) and sediment (qPCR; genome copies/g) from rural areas of the municipality of Rolante and Riozinho, Vale do Paranhana

\begin{tabular}{|c|c|c|c|c|c|}
\hline \multirow[b]{2}{*}{ Municipality } & \multirow[b]{2}{*}{ Source } & \multicolumn{2}{|c|}{ WATER } & \multicolumn{2}{|c|}{ SEDIMENT } \\
\hline & & qPCR & PCR & qPCR & PCR \\
\hline \multirow{10}{*}{ Riozinho } & \multirow{2}{*}{ Springs } & $7 / 10$ & $5 / 10$ & $5 / 6$ & $1 / 6$ \\
\hline & & $1.01 \times 10^{3}-2.08 \times 10^{8}$ & - & $7.51 \times 10^{3}-5.87 \times 10^{4}$ & - \\
\hline & \multirow{2}{*}{ Artesian Wells } & $9 / 9$ & $6 / 9$ & - & - \\
\hline & & $1.33 \times 10^{3}-1.26 \times 10^{4}$ & - & - & - \\
\hline & \multirow{2}{*}{ Dams } & $5 / 5$ & $2 / 5$ & $2 / 3$ & $1 / 3$ \\
\hline & & $4.43 \times 10^{3}-1.08 \times 10^{4}$ & - & $1.97 \times 10^{3}-2.36 \times 10^{4}$ & - \\
\hline & \multirow{2}{*}{ Streams } & $4 / 5$ & $1 / 5$ & $3 / 4$ & $1 / 4$ \\
\hline & & $4.08 \times 10^{3}-1.73 \times 10^{4}$ & - & $4.27 \times 10^{3}-1.96 \times 10^{4}$ & - \\
\hline & \multirow{2}{*}{ Tap Waters } & $1 / 2$ & $0 / 2$ & - & - \\
\hline & & $1.14 \times 10^{3}$ & - & - & - \\
\hline \multirow{10}{*}{ Rolante } & \multirow{2}{*}{ Springs } & $8 / 8$ & $6 / 8$ & $1 / 1$ & $1 / 1$ \\
\hline & & $1.38 \times 10^{3}-9.57 \times 10^{4}$ & & $1.66 \times 10^{4}$ & - \\
\hline & \multirow{2}{*}{ Artesian Wells } & $2 / 2$ & $1 / 2$ & - & - \\
\hline & & $3.87 \times 10^{3}-2.72 \times 10^{4}$ & - & - & - \\
\hline & \multirow{2}{*}{ Dams } & $3 / 3$ & $0 / 3$ & $1 / 2$ & $1 / 2$ \\
\hline & & $1.57 \times 10^{2}-2.08 \times 10^{3}$ & - & $7.67 \times 10^{3}$ & - \\
\hline & \multirow{2}{*}{ Streams } & $3 / 5$ & $0 / 5$ & $4 / 4$ & $2 / 4$ \\
\hline & & $1.94 \times 10^{3}-9.68 \times 10^{3}$ & - & $5.34 \times 10^{3}-6.96 \times 10^{4}$ & - \\
\hline & \multirow{2}{*}{ Tap Waters } & $6 / 6$ & $5 / 6$ & - & - \\
\hline & & $3.54 \times 10^{3}-6.71 \times 10^{4}$ & - & - & - \\
\hline
\end{tabular}

monitor the performance of the assay which has been shown to be cost effective when implemented in high performance laboratories ${ }^{22}$. Thus, the benefits of qPCR in relation to the conventional PCR are numerous and include time spent, reproducibility and the ability to quantitate the amplification target ${ }^{44}$. Tests have shown that $\mathrm{qPCR}$ detection sensitivities are comparable to, or higher than, that of conventional PCR ${ }^{9}$. However, the interpretation of results requires expertise and a trained team to ensure the accuracy of results.

In the present study, most of the viral loads of HAdV in water and sediment samples varied between $10^{3} \mathrm{gc}$ and $10^{4} \mathrm{gc} / \mathrm{L}$, while a single spring sample had $2.08 \times 10^{8} \mathrm{gc} / \mathrm{L}$. In all environmental matrices (springs, artesian wells, dams, streams, tap waters) tested here, more positive samples were obtained when analyzed by qPCR. Water samples (artesian wells and dams) were positive by qPCR while PCR found $47 \%$ of positivity. In sediment samples a $128 \%$ higher percentage of positive results were found by the quantitative method. The use of qPCR for the detection of HAdV has clearly indicated that low viral loads are not an obstacle in the search for pathogens in environmental samples when used with high sensitivity detection methods ${ }^{12}$. JIANG et al. $(2005)^{18}$ and ROMANOVA et al. (2009) ${ }^{33}$ reported that qPCR methodology is more sensitive for detection of $\mathrm{AdV}$ in environmental water samples; in addition, qPCR is less sensitive to amplification inhibitors ${ }^{8}$. Furthermore, qPCR has been generally accepted in research laboratories, mainly related to microbiology ${ }^{23}$.

Although conventional PCR and its variants can be highly sensitive and specific, they have some limitations, including the requirement of agarose or polyacrylamide gel electrophoresis, risk of carry-over, inability to quantify the amplification products present in the samples, and the use of reagents such as ethidium bromide which is detrimental to the health of handlers ${ }^{26}$. In conclusion, the qPCR for detection of HAdV in environmental samples (water and sediment) proved to be a reliable and cost-effective tool when compared to the conventional PCR tested here. Besides, amplification and detection are performed in a closed system, avoiding laborious post-PCR manipulation ${ }^{22}$.

\section{RESUMO}

\section{PCR quantitativa versus convencional para a detecção de adenovírus humano em amostras de água e sedimento}

Os adenovírus humanos (HAdV) são notavelmente resistentes ao ambiente. Estes agentes podem servir como indicadores efetivos 
STAGGEMEIER, R.; BORTOLUZZI, M.; HECK, T.M.S.; SPILKI, F.R. \& ALMEIDA, S.E.M. - Quantitative vs. conventional PCR for detection of human adenoviruses in water and sediment samples. Rev. Inst. Med. Trop. Sao Paulo, 57(4): 299-303, 2015.

de contaminação fecal, tanto quanto podem atuar como agentes causadores de diferentes doenças em seres humanos. A reação em cadeia da polimerase (PCR) e mais recentemente a PCR quantitativa (qPCR) são amplamente usadas para detecção de agentes virais em matrizes ambientais. No presente estudo, PCR e SYBR®Green qPCR foram comparadas para a detecção de HAdV em amostras de água (55) e sedimento (20) provenientes de nascentes, poços, açudes e arroios coletadas em propriedades leiteiras. A metodologia quantitativa detectou HAdV em 87,3\% das amostras de água e $80 \%$ dos sedimentos, enquanto por PCR convencional a detecção foi de $47,3 \%$ e $35 \%$, respectivamente.

\section{REFERENCES}

1. Allard A, Albinsson B, Wadell G. Detection of adenoviruses in stools from healthy persons and patients with diarrhea by two-step polymerase chain reaction. J Med Virol. 1992;37:149-57.

2. Balamurugan V, Jayappa KD, Hosamani M, Bhanuprakash V, Venkatesan G, Singh RK. Comparative efficacy of conventional and taqman polymerase chain reaction assays in the detection of capripoxviruses from clinical samples. J Vet Diag Invest. 2009;21:225-31.

3. Bastien P, Procop GW, Reischl U. Quantitative real-time PCR is not more sensitive than "conventional" PCR. J Clin Microbiol. 2008;46:1897-900.

4. Carson C, Quinnell RJ, Holden J, Garcez LM, Deborggraeve S, Courtenay O. Comparison of Leishmania OligoC-TesT PCR with conventional and real-time PCR for diagnosis of canine Leishmania infection. J Clin Microbiol. 2010;48:3325-30.

5. Carter MJ. Enterically infecting viruses: pathogenicity, transmission and significance for food and waterborne infection. J Appl Microbiol. 2005;98:1354-80.

6. Dagher H, Donninger H, Hutchinson P, Ghildyal R, Bardin P. Rhinovirus detection: comparison of real-time and conventional PCR. J Virol Methods. 2004;117:113-21

7. De Oliveira LK, Fleck JD, Comerlato J, Kluge M, Bergamaschi B, Fabres RB, et al. Enteric viruses in water samples from Brazilian dairy farms. Agric Water Manag. 2012;111:34-9.

8. De Paula VS, Diniz-Mendes L, Villar LM, Luz SL, Silva LA, Jesus MS, et al. Hepatitis A virus in environmental water samples from the Amazon Basin. Water Res. 2007;41:1169-76.

9. Donaldson KA, Griffin DW, Paul JH. Detection, quantitation and identification of enteroviruses from surface waters and sponge tissue from the Florida Keys using real-time RT-PCR. Water Res. 2002;36:2505-14.

10. Ferreira ID, Rosário VE, Cravo PV. Real-time quantitative PCR with SYBR Green I detection for estimating copy numbers of nine drug resistance candidate genes in Plasmodium falciparum. Malar J. 2006;5:1.

11. Flori P, Bellete B, Durand F, Raberin H, Cazorla C, Hafid J, et al. Comparison between real-time PCR, conventional PCR and different staining techniques for diagnosing Pneumocystis jiroveci pneumonia from bronchoalveolar lavage specimens. J Med Microbiol. 2004;53:603-7.

12. Fong TT, Lipp EK. Enteric viruses of humans and animals in aquatic environments: health risks, detection, and potential water quality assessment tools. Microbiol Mol Biol Rev. 2005;69:357-71.

13. Fongaro G, Nascimento MA, Rigotto C, Ritterbusch G, da Silva AD, Esteves PA, et al. Evaluation and molecular characterization of human adenovirus in drinking water supplies: viral integrity and viability assays. Virol J. 2013;10:166.

14. Ginzinger DG. Gene quantification using real-time quantitative PCR: an emerging technology hits the mainstream. Exp Hematol. 2002;30:503-12.
15. Griffin DW, Donaldson KA, Paul JH, Rose JB. Pathogenic human viruses in coastal waters. Clin Microbiol Rev. 2003;16:129-43.

16. He JW, Jiang S. Quantification of enterococci and human adenoviruses in environmental samples by real-time PCR. Appl Environ Microbiol. 2005;71:2250-5.

17. International Committee on Taxonomy of Viruses. Virus taxonomy: 2013 release. Available from: http://www.ictvonline.org/virusTaxonomy.asp?version=2013

18. Jiang SC, Dezfulian H, Chu W. Real-time quantitative PCR for enteric adenovirus serotype 40 in environmental waters. Can J Microbiol. 2005;51:393-8.

19. Jiang SC. Adenovirus as an index of human viral contamination. Microbiological Source Tracking Workshop. Proceedings. Irvine; 2001. p. 75-8.

20. Katayama H, Shimasaki A, Ohgaki S. Development of a virus concentration method and its application to detection of enterovirus and Norwalk virus from coastal seawater. Appl Environ Microbiol. 2002;68:1033-9.

21. Lee SH, Lee C, Lee KW, Cho HB, Kim SJ. The simultaneous detection of both enteroviruses and adenoviruses in environmental water samples including tap water with an integrated cell culture-multiplex nested PCR procedure. J Appl Microbiol. 2005;98:1020-9.

22. Mackay IM, Arden KE, Nitsche A. Real-time PCR in virology. Nucleic Acids Res. 2002;30:1292-305.

23. Mackay IM. Real-time PCR in the microbiology laboratory. Clin Microbiol Infect 2004;10:190-212.

24. Magalhães GF, Nogueira PA, Grava AF, Penati M, Silva LH, Orlandi PP. Rotavirus and adenovirus in Rondônia. Mem Inst Oswaldo Cruz. 2007;102:555-7.

25. Mygind T, Birkelund S, Birkebaek N, Østergaard L, Jensen JS, Christiansen G. Determination of PCR efficiency in chelex-100 purified clinical samples and comparison of real-time quantitative PCR and conventional PCR for detection of Chlamydia pneumoniae. BMC Microbiol. 2002;2:17.

26. Paiva-Cavalcanti M, Regis-da-Silva CG, Gomes YM. Comparison of real-time PCR and conventional PCR for detection of Leishmania (Leishmania) infantum infection: a mini-review. J Venom Anim Toxins Incl Trop Dis. 2010;16:537-42.

27. Piranha JM, Pacheco A, Gamba RC, Mehnert DU, Garrafa P, Barrella KM. Fecal contamination (viral and bacteria) detection in groundwater used for drinking purposes in São Paulo, Brazil. Geomicrobiol J. 2006;23:279-83.

28. Prado T, Silva DM, Guilayn WC, Rose TL, Gaspar AM, Miagostovich MP. Quantification and molecular characterization of enteric viruses detected in effluents from two hospital wastewater treatment plants. Water Res. 2011;45:1287-97.

29. Pusch D, Oh DY, Wolf S, Dumke R, Schröter-Bobsin U, Höhne M, et al. Detection of enteric viruses and bacterial indicators in German environmental waters. Arch Virol. 2005;150:929-47.

30. Raboni SM, Damasio GA, Ferreira CE, Pereira LA, Nogueira MB, Vidal LR, et al. Acute gastroenteritis and enteric viruses in hospitalised children in southern Brazil: aetiology, seasonality and clinical outcomes. Mem Inst Oswaldo Cruz. 2014;109:428-35.

31. Riedel TE, Zimmer-Fausta AG, Thulsiraj V, Madi T, Hanley KT, Ebentier DL, et al. Detection limits and cost comparisons of human- and gull-associated conventional and quantitative PCR assays in artificial and environmental waters. J Environ Manage. 2014;136:112-20.

32. Robledo G, González CI, Morillo C, Martín J, González A. Association study of PTPN22 C1858T polymorphism in Trypanosoma cruzi infection. Tissue Antigens. 2007;69:261-4.

33. Romanova N, Corredor JC, Nagy E. Detection and quantification of fowl adenovirus genome by a real-time PCR assay. J Virol Methods. 2009;159:58-63. 


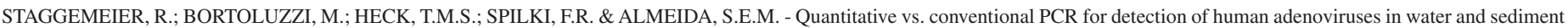
samples. Rev. Inst. Med. Trop. Sao Paulo, 57(4): 299-303, 2015.

34. Shenk T. Adenoviridae: the viruses and their replication. In: Fields virology. Fields BN, Knipe DM, Howley PM, editors-in-chief. $3^{\text {rd }}$ ed. Philadelphia: Lippincott-Raven; 1996. v. 2. p. $2111-48$

35. Smith CJ, Osborn AM. Advantages and limitations of quantitative PCR (Q-PCR)-based approaches in microbial ecology. FEMS Microbiol Ecol. 2009;67:6-20.

36. Topcuoglu N, Paltura C, Kulekci M, Ustek D, Kulekci G. Real-time polymerase chain reaction versus conventional PCR: a comparison between two methods for the detection of Fusobacterium nucleatum in saliva, nasopharyngeal secretion and middle ear effusion samples. Biotechnol Biotechnol Equip. 2013;27:3825-8.

37. United States. Environmental Protection Agency. CCL 2 list \& regulatory determinations: 2005. Available from: http://water.epa.gov/scitech/drinkingwater/dws/ccl/ccl2.cfm

38. Vecchia AD, Fleck JD, Comerlato J, Kluge M, Bergamaschi B, da Silva JV, et al. First description of Adenovirus, Enterovirus, Rotavirus and Torque teno virus on water samples collected from the Arroio Dilúvio, Porto Alegre, Brazil. Braz J Biol. 2012;72:323-9.

39. Victoria M, Guimarães F, Fumian T, Ferreira F, Vieira C, Leite JP, et al. Evaluation of an adsorption-elution method for detection of astrovirus and norovirus in environmental waters. J Virol Methods. 2009;156:73-6.
40. Villar LM, de Paula VS, Diniz-Mendes L, Guimarães FR, Ferreira FF, Shubo TC, et al Molecular detection of hepatitis A virus in urban sewage in Rio de Janeiro, Brazil. Lett Appl Microbiol. 2007;45:168-73.

41. Villar LM, de Paula VS, Diniz-Mendes L, Lampe E, Gaspar AM. Evaluation of methods used to concentrate and detect hepatitis A virus in water samples. J Virol Methods. 2006; $137: 169-76$

42. Wolf S, Hewitt J, Greening GE. Viral multiplex quantitative PCR assays for tracking sources of fecal contamination. Appl Environ Microbiol. 2010;76:1388-94.

43. Xagoraraki I, Kuo DH, Wong K, Wong M, Rose JB. Occurrence of human adenoviruses at two recreational beaches of the great lakes. Appl Environ Microbiol. 2007;73:7874 81 .

44. Yang S, Rothman RE. PCR-based diagnostics for infectious diseases: uses, limitations and future applications in acute-care settings. Lancet Infect Dis. 2004;4:337-48.

Received: 10 August 2014

Accepted: 3 November 2014 


\section{LIBRARY OF THE \\ SÃO PAULO INSTITUTE OF TROPICAL MEDICINE}

Website: http://www.imt.usp.br/sobre-o-imtsp/biblioteca

Address: Biblioteca do Instituto de Medicina Tropical de São Paulo da Universidade de São Paulo Av. Dr. Enéas de Carvalho Aguiar, 470.

05403-000 - São Paulo - SP - Brazil.

Telephone: 5511 3061-7003
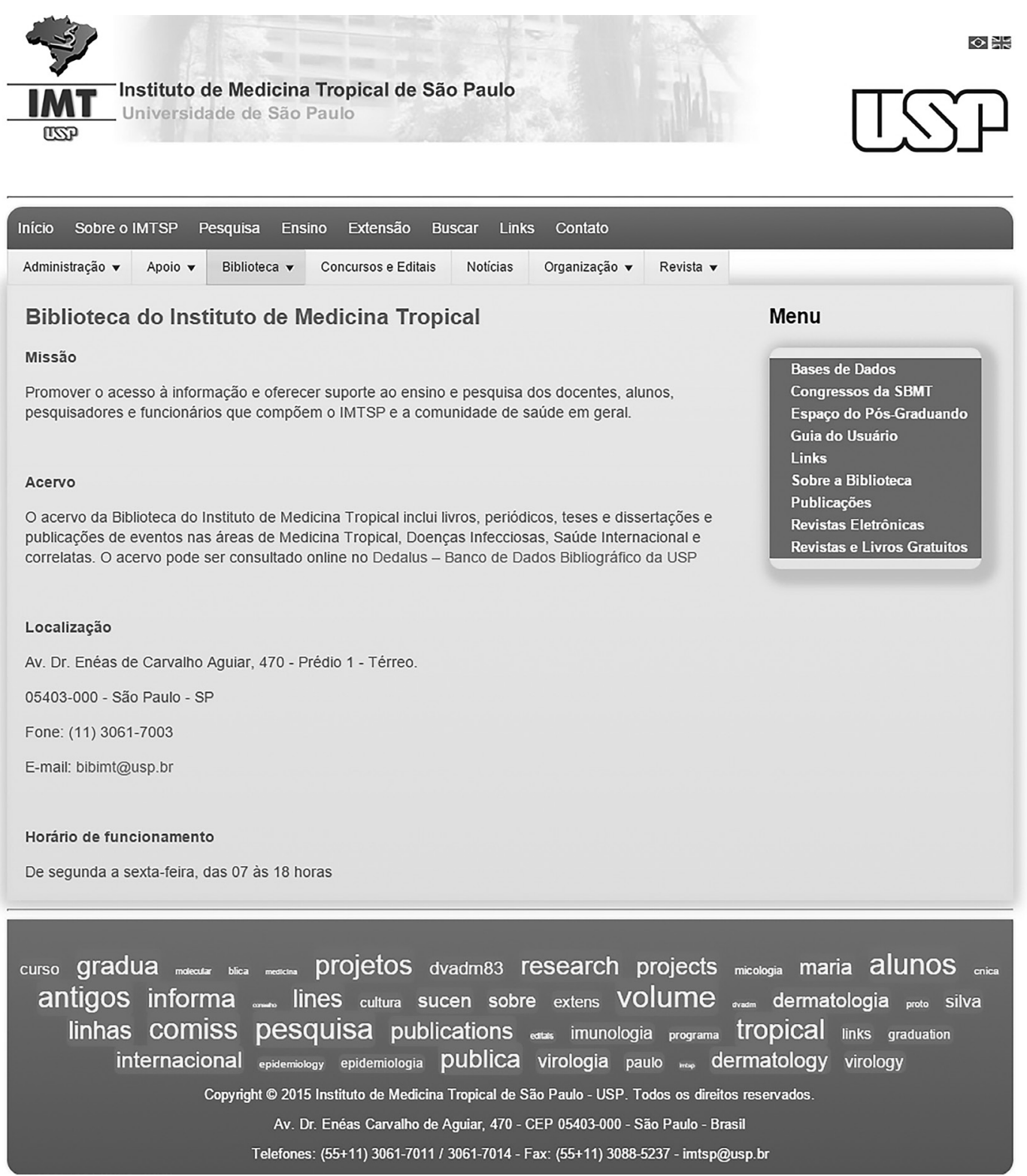

The Library of the São Paulo Institute of Tropical Medicine (IMTSP Library) was created on January 15, 1959 in order to serve all those who are interested in tropical diseases.

The IMTSP Library has a collection consisting of books, theses, annals of congresses, journals, and reference works.

The collection of the Library can be searched through the USP Bibliographic Database - Dedalus at the URL http://200.144.190.234/F 